\title{
Tissue engineering perspectives in dentistry: review of the literature
}

\section{Perspectivas da engenharia tecidual na Odontologia: revisão de literatura}

\author{
Juliana da Silva MORO1 ID 0000-0001-9011-9600 \\ Raquel Cristine Silva BARCELOS ${ }^{2}$ (D) 0000-0003-4399-2196 \\ Thiago Gomes TERRA ${ }^{3}$ ID 0000-0003-1693-4978 \\ Cristiane Cademartori DANESI ${ }^{4}$ (ID) 0000-0001-9170-5791
}

\section{ABSTRACT}

Tooth losses due to pathological processes continue to be a reality in daily clinical dentistry, inducing functional and psychological complications in patients. In view of this, a new option for the management of this problem - tissue engineering - has been studied in Dentistry. This field, considered multidisciplinary, uses three key elements for tissue regeneration: scaffolds (extracellular matrices) - natural or synthetic; cells, and growth factors. In this sense, combination of these three elements may induce regeneration of the dental pulp, bone and periodontal tissue, among others. Therefore, the aim of this study was to conduct a literature review, describing the main elements of tissue engineering and their applicability in Dentistry, as a means of updating dental surgeons about this subject.

Indexing terms: Tissue engineering. Dentistry. Cell- and tissue-based therapy.

\section{RESUMO}

As perdas dentárias, devido aos processos patológicos, ainda são uma realidade na clínica odontológica diária, induzindo complicações funcionais e psicológicas ao paciente. Diante disso, uma nova opção para o manejo desse problema vem sendo estudada na Odontologia, a engenharia tecidual. Essa área, considerada multidisciplinar, utiliza três elementos chaves para a regeneração dos tecidos: os scaffolds (matriz extracelular) naturais ou sintéticos, as células e os fatores de crescimento. Nesse sentido, a combinação desses três elementos pode induzir a regeneração da polpa dentária, tecido ósseo e periodontal, entre outros. Portanto, o objetivo deste estudo é realizar uma revisão da literatura, descrevendo e atualizando os cirurgiões-dentistas sobre os principais elementos da engenharia tecidual e sua aplicabilidade na Odontologia.

Termos de indexação: Engenharia tissular. Odontologia. Terapia baseada em transplante de células e tecidos.

\section{Pr}

1 Universidade Federal de Santa Maria, Programa de Pós-Graduação em Ciências Odontológicas. Santa Maria, RS, Brasil.

2 Universidade Federal de Santa Maria, Programa de Pós-Graduação em Farmacologia. Santa Maria, RS, Brasil.

${ }^{3}$ Centro Universitário Franciscano, Curso de Engenharia Biomédica. Santa Maria, RS, Brasil.

${ }^{4}$ Universidade Federal de Santa Maria, Departamento de Patologia. Av. Roraima, 1000, Camobi, 97105-900, Santa Maria, RS, Brasil. Correspondência para / Correspondence to: JS MORO. E-mail: <juliana.moroo@hotmail.com>.

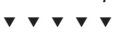

Como citar estar artigo / How to cite this article

Moro JS, Barcelos RCS, Terra TG, Danesi CC. I. Tissue engineering perspectives in dentistry: review of the literature. RGO, Rev Gaúch Odontol. 2018;66(4):361-367. http://dx.doi.org/10.1590/1981-8637201800040000103409 


\section{INTRODUCTION}

Transplantation is a surgical procedure that consists of replacing an organ or tissue of a sick person (receptor), with another normal organ or tissue of a living or dead donor. With increasing life expectancy and consequent population aging, there are a growing number of older persons with chronic-degenerative problems and need of organ transplants $[1,2]$. However, the scarcity of organs and risk of infections and rejections during this surgical procedure have driven the quest for alternatives to this technique [3]. From this aspect, tissue engineering has appeared with the purpose of regenerating damaged tissues, restoring their function without the need for replacing the diseased tissue [4].

The field of tissue engineering is highly multidisciplinary, as it involves the concepts of Medicine, Engineering and Genetics [5]. Furthermore, this field is based on three fundamental principles, namely: (I) the cells, responsible for synthesis of the new tissue matrix; (II) growth factors that promote and facilitate cell function; (III) and scaffolds that act as an extracellular matrix, allowing cell differentiation, proliferation and biosynthesis $[5,6]$.

In Dentistry, there is need of regenerative therapies that would be capable of recovering the function of tissues lost due to oral, maxillofacial and dental pathologies of traumatic, inflammatory and neoplastic origin, such as diseases of endodontic, periodontal, dental caries, facial trauma origin, among others7. In view of the foregoing, attempts relative to regeneration of the dental-pulp complex, as well as bone and cartilage regeneration, by using scaffolds containing stem cells have been extensively researched [6-8].

In this context, the present article intended to describe the main elements of tissue engineering and its applicability in Dentistry, and update dental surgeons about this topic.

\section{Fundamental elements for tissue engineering}

For tissue regeneration, the integration of three elements is required, namely: the cells, scaffolds or extracellular matrix, and growth factors [5] (figure 1).

\section{Cells}

Tissue regeneration requires specialized cells capable of synthesizing the extracellular matrix specific for each tissue [8]. In this sense, stem cells have been extensively used in regenerative medicine, since they are non-specialized and are capable of self-renewal and cell differentiation [9]. Stem cells may be classified according to their nature, into embryonic or adult types $[10,11]$. Embryonic stem cells are pluripotent and apt to differentiate into cells of the three germinative layers (ectoderm, mesoderm and endoderm) that consequently, may differentiate into multiple tissue cell types [12]. However, in spite of this high potential differentiation, these cells raise ethical questions, such as possible tumorigenic potential, making it difficult to use them $[13,14]$. Whereas, adult cells have been more frequently studied in regenerative medicine, because they are readily available, in addition to being capable of differentiating into various cell types, such as osteoblasts, chondrocytes, myoblasts, hematopoietic and neural cells, originating bone, cartilage, muscle, vascular and nerve tissue, respectively [6-9]. These cells may be found in bone marrow, adipose tissue, umbilical cord and in dental tissues [14-16]. With reference to dental tissues, various types of adult cells have been isolated from the periodontal ligament, papillae, primary and permanent tooth pulp, and are considered promising alternative for tissue engineering [17-21].

The stem cells of dental origin, also denominated dental mesenchymal stem cells -MSCs, perform an important function in dental repair and homeostasis, and present characteristics similar to those originated in bone marrow. Moreover, these cells are denominated according to their tissue of origin, such as stem cells from human exfoliated deciduous teeth - SHED); dental pulp stem cells - DPSCs); periodontal ligament stem cells - PDLSCs), among others [22].

The stem cells found in primary tooth pulp present high potential differentiation into odontoblasts, osteoblasts, adipocytes and chondrocytes [18-23]. Those derived from permanent teeth, specifically found in third molar pulp, may differentiate into odontoblasts, adipocytes, chondrocytes and myoblasts $[15,24,25]$. Both primary and permanent tooth sources of stem cells may be used for endodontic and bone regeneration. Whereas the stem cells found in periodontal ligaments differentiate into osteoblasts, cementoblasts and fibroblasts, and can be used in regenerating both periodontal ligaments and bone tissues $[17,26,27]$. 

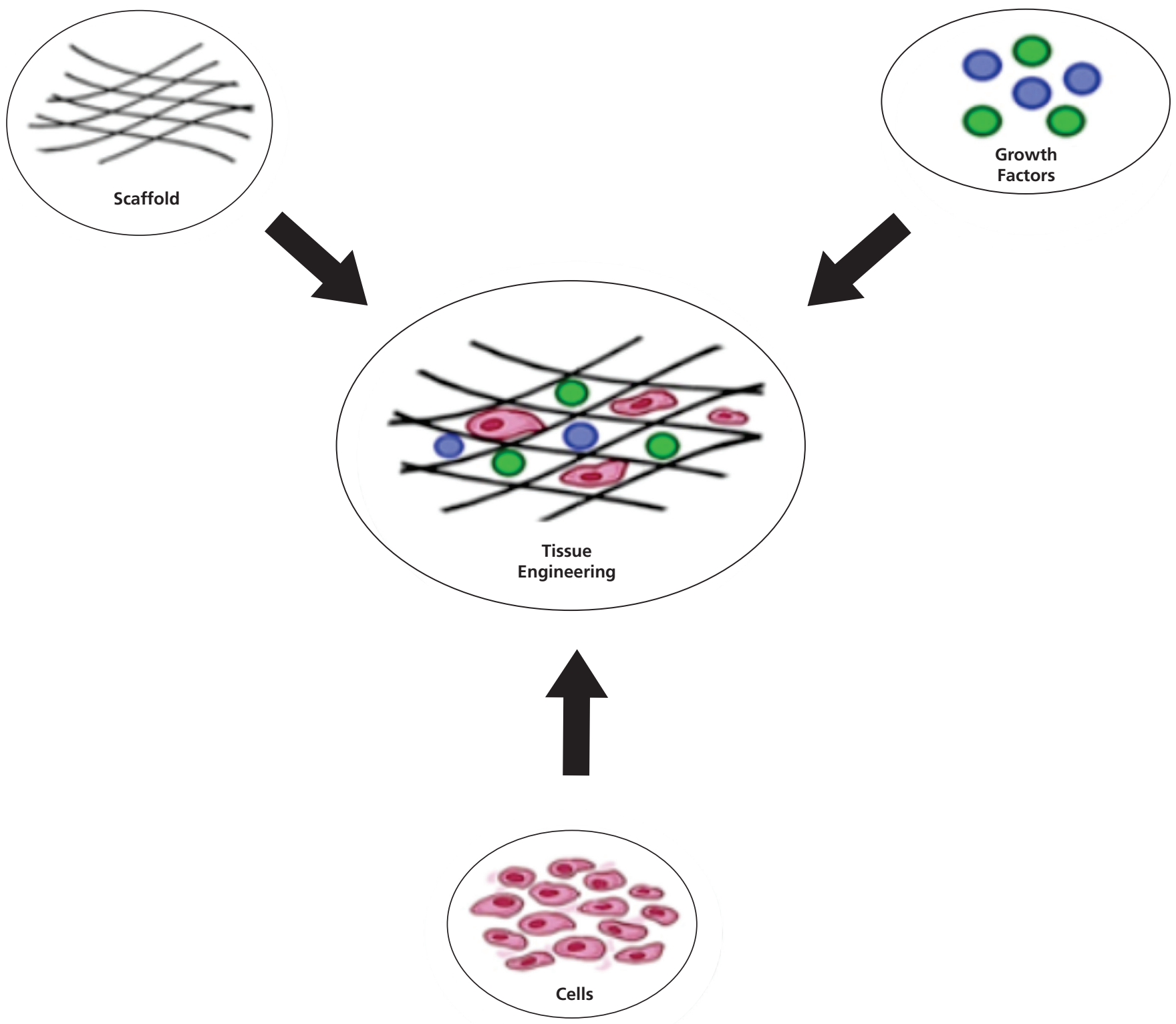

Figure 1. Triad of tissue engineering 1.

\section{Scaffolds or extracellular matrix}

Scaffolds are biomaterials with two-dimensional or three-dimensional architecture that provide the cells with an adequate environment, making it possible for them to migrate, proliferate and differentiate. In addition, they allow the transportation of nutrients, oxygen and cellular metabolic residues, making them a crucial element for tissue regeneration [28].

To be considered ideal, this biomaterial needs to present some characteristics, such as biocompatibility, biodegradability, good mechanical properties, and a porous structure [13]. Biocompatibility is one of the main characteristics that must be present, because it prevents immunological cytotoxic and inflammatory reactions by the body, which impede the regenerative performance of the biomaterial [29]. Moreover, the capacity for biodegradability allows the cells of the body itself to degrade the scaffold, and to make space for new tissue [30]. Moreover, scaffolds need to have good mechanical properties and compatibility with those of the tissue or organ to be replaced. However, materials with these characters continue to be a challenge 
to tissue engineering [4]. Of fundamental importance as well, is that scaffolds must have pores with an adequate size and dispersion ability, since these features ensure cell penetration, diffusion of the nutrients required by the cells, vascularization of the site and removal of the residual products by taking them out of the structure [31].

The choice of material for fabricating the scaffold is also an important factor for it to be successful. Different types of materials may be used, such as ceramics, metals and polymers. In this context, polymers have gained emphasis because they have biogradability and great flexibility in their processing [3]. Polymers may be of natural origin, and be composed of collagen, fibrin and hyaluronic acid; synthetic, made of polymer compounds such as Poly (lactic acid) (PLA), polyglycolic acid (PGA) and its poly copolymer (Poly(Lactide-co-Glycolide) acid) (PLGA); or hybrids (natural and synthetic) [32]. However, synthetic materials have shown a higher success rate when compared with the natural types, because they provide versatility when creating the scaffold architecture, allowing control of the mechanical, physical and degradation properties [3].

Various techniques are involved in the fabrication of scaffolds, such as lyophilizing, phase separating, foaming, rapid prototyping, and electrospinning, among others. However, the electrospinning technique has advantages compared with other techniques, because it is easy to perform, versatile, and allows better control of pore fabrication [28-33].

\section{Growth factors}

Growth factors are extracellularly secreted proteins that stimulate cell growth and bind to specific receptors in the cell membranes. Furthermore, the have the capacity to regulate cell growth, development proliferation and migration [34].

Different growth factors have been used in tissue engineering, among them are the bone morphogenetic proteins (BMP); Hedgehog proteins (HHS); fibroblast growth factor (FGF); interleukins; tumor necrosis factor (TNF) and vascular endothelial growth factor (VEGF) [35]. Among these signaling molecules, the BMPs have been extensively studied and applied for dental regeneration [35]. The BMPs can be divided into four families: the first are BMP-2 and -4 ; second, BPM-3 and -3B; the, BMP-5, $-6,-7$ and -8 ; and lastly, the GDF-5, -6 and -7 (growth/ differentiation factors). These proteins play an important role in tooth development, and are associated with the differentiation of odontoblasts and ameloblasts, and in the development of cement and alveolar bone [36,37].

In one study, using an animal model of periodontal disease, the regeneration and healing potential of BMP- 6 was evaluated in periodontal defects. After the onset of periodontal disease, BMP- 6 was applied to the affected regions and maintained for 8 weeks. At the end of the study, the authors observed that the application of BPMs- 6 in the areas of bone loss increased healing and the bone and ligament regeneration, demonstrating the importance of this protein in regenerative dentistry [38].

\section{Tissue engineering applications in Dentistry}

In spite of reduction the prevalence of tooth losses in adolescents and adults, over half the older population in Brazil is still edentulous [39]. As a result of this, there has been an increasing demand for dental implants and alternatives for recovering oral health. However, the lack of bone support, defects at the implant placement site, and failure of bone grafts may compromise the success of treatment [40]. In view of this, the purpose of tissue energy is to regenerate the bone and dental tissues, thereby restoring the patient's quality of life.

Firstly, the replace a dental tissue, it is necessary to understand its complex mechanism of development and its cellular interactions, and from there on, reproduce these in the laboratory. From this aspect, researchers use four laboratory techniques, among them are the use of biocompatible molds, tissue recombination, dental construction and induction of the third dentition. Of these, the former two are most used, and consist of using molds in tooth format made of polymers, or recombine cells of different origins to interact among them, thereby originating a new dental tissue, respectively [41].

As regards dental pulp regeneration, researches have shown promising results over the past few years. This could be observed in the study of Wang and collaborators [42], in which they evaluated the potential for pulp regeneration using stem cells derived from the dental pulp of animals. The authors observed rapid differentiation and proliferation of stem cells, generating vascularized pulp tissues, proving the feasibility of tissue engineering. Another in vitro and in vivo study conducted in 2015, 
investigated the effects of Platelet-rich fibrin (PRP) in the stem cells originated from dental pulp, and the potential revascularization and regeneration of pulp tissue. At the end of the two experiments, the researchers noted that platelet-rich fibrin not only promoted the proliferation of stem cells in vitro, but also regeneration of the pulp and capillary blood vessels in the intracanal walls of the animals' teeth [43].

Bone tissue has also been the target of researchers, mainly using mesenchymal stem cells and BMPs, because they have characteristics that induce bone formation [38-44]. In relation to scaffolds, in addition to the essential characteristics mentioned previously, such as biocompatibility, biodegradability, porosity and good mechanical properties, these must be osteoconductors, providing a micro-environment that integrates the bone to the host bone tissue [8]. In this context, biomaterials with hydroxyapatite help with cell adhesion and induce the differentiation of osteoprogenitor cells [45]. However, as yet there are no scaffolds with all of the criteria necessary for bone regeneration, limiting the development of this technique in tissue generation [46].

In addition to the above-mentioned tissues, innumerable researches have been directed towards periodontal regeneration, particularly the development of new cement with fibers connected to the alveolar bone $[47,48]$. For this purpose, the use of growth factors and cytokines may stimulate formation of these tissues. As an example of this, Sakaguchi et al. [49] used a mixture of growth factors (IGF-1; VEGF-A; TAFT- $\beta 1$ ) and mesenchymal stem cells derived from bone marrow and the periodontal ligament of dogs to promote periodontal tissue regeneration. On conclusion of the research, the authors observed that the growth factors concomitant with the cytokines promoted angiogenesis and the new tissue formation in the furca defects induced by the periodontal disease in the animals. Simultaneously with growth factors and stem cells, the scaffolds act in an important way in periodontal regeneration, promoting bone growth and preventing the epithelial tissue from infiltrating into the bone defect site and making it difficult for tissue to grow [50].

Another aspect to be emphasized refers to tissue generation of the temporomandibular joint (TMJ), since a large portion of the population suffers from disturbances in this region, causing pain that interferes in the quality of life [40]. This is why studies have investigated materials for cellular support that help with the regeneration of cartilage, a tissue present in the articular disc of the TMJ and which provides this structure with physical and functional support [6]. Among these materials, the natural polymers such as collagen and gelatin are outstanding, because there have been studies with promising reports. In addition to these, other materials are being evaluated, including hyaluronic acid, fibrin, silk and synthetic polymers such as PLGA and Polyvinyl alcohol (PVA) [51]. With reference to cells and growth factors, cells extracted from the sinovial capsule and fibroblast growth factors (bFGF), TAFT- $\beta 1$ e IGF-1, have also shown promising results in regenerating the cartilage of the TMJ [40-51]. Nevertheless, this region is one of the most challenging for regenerative treatment, because it has a limited capacity for self-repair and a poor blood supply. Moreover, there is the possibility of fibrous adhesions and ossification occurring in its structure during surgical procedure, so that further studies to resolve these limitations are necessary [40].

\section{FINAL CONSIDERATIONS}

The future of tissue engineering in Dentistry is most promising, and this new approach is expected to enable regeneration of tissues damaged by the different dental pathologies. A great deal of progress has been made in the researches, with the development of different materials and fabrication techniques, with the purpose of improving the properties of the materials for this field of interest. However, in spite of these advances, complete regeneration of dental tissues continues to be challenging. Therefore, dentists must be aware of these advances, help with the development of researches, and use the new technologies in daily clinical practice, thereby providing patients with more efficient therapy, and consequently, improvement in their quality of life.

\section{Collaborators}

JS MORO, RCS BARCELOS and TG TERRA, participated in the search for articles for the preparation of the review, review of manuscript writing and approved the final version. CC DANESI, review of manuscript writing and approved the final version.

\section{REFERENCES}

1. Langer R. Tissue engineering. Mol Ther. 2000;1(1):12-5. https:// doi.org/10.1006/mthe.1999.0003 
2. Cummings SR, Melton LJ. Epidemiology and outcomes of osteoporotic fractures. Lancet. 2002;359(9319):1761-1767. https://doi.org/10.1016/S0140-6736(02)08657-9

3. Bajaj P, Schweller RM, Khademhosseini A, West JL, Bashir R. 3D Biofabrication Strategies for Tissue Engineering and Regenerative Medicine. Annu Rev Biomed Eng. 2014;16:247-76. https://doi.org/10.1146/annurev-bioeng-071813-105155

4. O'Brien F. Biomaterials \& scaffolds for tissue engineering. Mat Today. 2011;14(3):88-95. https://doi.org/10.1016/\$1369-70 21(11)70058-X

5. Ikada $Y$. Challanges in tissue engineering. J R Soc Interface. 2006;3(10):589-601. http://dx.doi.org/10.1098/rsif.2006.01 24

6. Rai R. Tissue engineering: step ahead in maxillofacial reconstruction. J Int Oral Health. 2015;9(7):138-142.

7. Bossu M, Maurizio B, Andrea P, Daniele C, Gianluca T, Gaetano I, et al. Today prospects for tissue engineering therapeutic approach in Dentistry. Scientific World J. 2014;14:151-252. http://dx.doi.org/10.1155/2014/151252.

8. Zaky SH, Cancedda R. Engineering craniofacial structures: facing the challenge. J Dent Res. 2009;88(12):1077-1091. http://dx.doi.org/10.1177/0022034509349926

9. Conrad C, Huss. R. Adult stem cell lines in regenerative medicine and reconstructive surgery. J Surg Res. 2005;201-208. http://dx.doi.org/10.1016/j.jss.2004.09.015

10. Souza V. Células-tronco: uma breve revisão. Rev Cienc Méd Biol. 2003;2(2):251-256.

11. Rocha AS, Maia L, Guastali MD, Volpato R, Alvarenga, FCL. Considerações sobre células-tronco embrionárias. Vet Zootec. 2012;19(3):303-313.

12. Rao BM, Zandstra PW. Culture development for human embryonic stem cell propagation: molecular aspects and challenges. Curr Opin Biotechnol. 2005;16:568-576. https:// doi.org/10.1016/j.copbio.2005.08.001

13. Al himdami S, Jessop ZM, Al- Sabah A, Combellack E, Ibrahim A, Doak SH, et al. Tissue-Engineered Solutions in Plastic and Reconstructive Surgery: Principles and Practice. Front Surg. 2017;4:4. https://doi.org/10.3389/fsurg.2017.00004

14. Eke G, Mangir N, Hasirci N. Development of a UV crosslinked biodegradable hydrogel containing adipose derived stem cells to promote vascularization for skin wounds and tissue engineering. Biomaterials. 2017; 129:188-198. https://doi. org/10.1016/j.biomaterials.2017.03.021

15. Piva E, Susan AT, Jacques EN. Dental pulp tissue regeneration using dental pulp stem cells isolated and expanded in human serum. J Endod. 2017;43(4):568-574. https://doi.org/10.10 16/j.joen.2016.11.018

16. Silva ML, Caplan Al, Nardi NB. In search of the in vivo identity of mesenchymal stem cells. Stem Cells. 2008; 26(9):22872299. https://doi.org/10.1634/stemcells.2007-1122

17. Iriarte CGT, Ramirez OR, Garcia AM, Terán SLV, Clavel JFG. Isolation of periodontal ligament stem cells from extracted premolars. Simplified method. Rev Mexicana Odont. 2017; 21(1):12-20. https://doi.org/10.1016/j.rodmex.2017.02.006

18. Miura M, Gronthos S, Zhao M. SHED: stem cells from human exfoliated deciduous teeth. Proc Natl Acad Sci USA.
2003;100(10):5807-5812. https://doi.org/10.1073/pnas.093 7635100

19. Sonoyama YW, Liu T, Yamaza. Characterization of the apical papilla and its residing stem cells from human immature permanent teeth: a pilot study. J Endod. 2008;34(2):166-171. https://doi.org/10.1016/j.joen.2007.11.021

20. Cherpa V. Survival of the apical papilla and its resident stem cells in a case of advanced pulpal necrosis and apical periodontitis. J Endod. 2017;43(4):561-567. https://doi. org/10.1016/j.joen.2016.09.024

21. Giudice FS, Sperandio FF, Mantesso A. Células tronco de origem dental: populações e características. RPG Rev Pós Grad. 2009;16(4):160-7.

22. Sharpe PT. Dental mesenchymal stem cells. Development. 2016; 143:2273-80. https://doi.org/10.1242/dev.134189

23. Nourbakhsh N. Induced in vitro differentiation of neurallike cells from human exfoliated deciduous teeth-derived stem cells. Int J Dev Biol. 2011;55(2):189-95. https://doi. org/10.1387/ijdb.103090nn

24. Zhang W, Walboomers XF, van Kuppevelt TH, Daamen WF, van Damme PA, Bian Z, et al. In vivo evaluation of human dental pulp stem cells differentiated towards multiple lineages. J Tissue Eng Regen Med. 2008;2(2-3):117-25. https://doi.org/10. 1002/term. 7

25. D'Alimonte I, Mastrangelo F, Giuliani P, Pierdomenico L, Marchisio M, Zuccarini M, et al. Osteogenic differentiation of mesenchymal stromal cells: a comparative analysis between human subcutaneous adipose tissue and dental pulp. Stem Cells Dev. 2017;26(11):843-855. https://doi.org/10.1089/scd. 2016.0190

26. Wang WJ, Zhao YM, Lin BC, Yang J, Ge LH. Identification of multipotent stem cells from adult dog periodontal ligament. Eur J Oral Sci. 2012;120(4):303-10. https://doi.org/10.1111/ j.1600-0722.2012.00975.x

27. Kim SH, Kim KH, Seo BM, Koo KT, Kim TI, Seol YJ, et al. Alveolar bone regeneration by transplantation of periodontal ligament stem cells and bone marrow stem cells in a canine peri-implant defect model: a pilot study. J Periodontol. 2009;80(11):1815-23. https://doi.org/10.1902/jop.2009.090249

28. Le X, Poinern EJ, Ali N, Berry CM, Fawcett D. Engineering a biocompatible scaffold with either micrometre or nanometre scale surface topography for promoting protein adsorption and cellular response. Int J Biomater. 2013;100(10):5807-5812. https://doi.org/10.1073/pnas.0937635100

29. Brown BN, Valentin JE, Stewart-Akers AM, McCabe GP, Badylak SF. Macrophagephenotype and remodeling outcomes in response to biologic scaffolds with and without a cellular component. Biomaterials. 2009 Mar; 30(8):1482-91. https:// doi.org/10.1016/j.biomaterials.2008.11.040

30. Hutmacher DW. Scaffold design and fabrication technologies for engineering tissues--state of the art and future perspectives. J Biomater Sci Polym Ed. 2001;12(1):107-24.

31. Baolin G, Peter XMA. Synthetic biodegradable functional polymers for tissue engineering: a brief review. Sci China Chem. 2014;57(4):490-500. 
32. Zhu N, Chen X. Biofabrication of tissue scaffolds. Intech. 2013;12:312-27. https://doi.org/10.5772/54125

33. Zhao HY. Research Advances in Tissue Engineering Materials for Sustained Release of Growth Factors. Biomed Res Int. 2015;2015:808202. doi: 10.1155/2015/808202

34. Patil AS, Merchant Y, Nagarajan P. Tissue engineering of craniofacial tissues: a review. J Regen Med Tissue Eng. 2013;2:6. https://doi.org/10.7243/2050-1218-2-6

35. Nakashima $M$, Reddi $H$. The application of bone morphogenetic proteins to dental tissue engeneering. Nat Biotechnol. 2003;21(9):1025-32. https://doi.org/10.1038/nbt 864

36. Thesleff I, Sharpe P. Signalling networks regulating dental development. Mech Dev. 1997;67(2):111-23.

37. Chiu HC. Effects of bone morphogenetic protein- 6 on periodontal wound healing/regeneration in supra alveolar periodontal defects in dogs. J Clin Periodontol. 2013;40:62430. https://doi.org/10.1111/jcpe.12075

38. Peres MA, Barbato PR, Guimarães SC, Reis B, Freitas CHSM, Antunes JLF. Perdas dentárias no Brasil: análise da Pesquisa Nacional de Saúde Bucal 2010. Rev Saúde Pública. 2013;47(3):78-89. https://doi.org/10.1590/S00348910.2013047004226

39. Neel EAA. Tissue engineering in Dentistry. J Dent. 2014;42(8):915-28. https://doi.org/10.1016/j.jdent.2014.05. 008

40. Daltoé FP, Miguita L, Mantesso A. Terceira dentição: uma visão geral do seu desenvolvimento. RGO, Rev Gaúch Odontol. 2010;58(3):387-392.

41. Wang Y, Zhao Y, Jia W, Yang J, Ge L. Preliminary study on dental pulp stem cell-mediated pulp regeneration in canine immature permanent teeth. J Endod. 2013;39:195-201. https:// doi.org/10.1016/j.joen.2012.10.002

42. Chen YJ, Zhao YH, Zhao YJ, Liu NX, Lv X, Li Q, et al. Potential dental pulp revascularization and odonto-/osteogenic capacity of a novel transplant combined with dental pulp stem cells and platelet-rich fibrin. Cell Tissue Res. 2015;361(2):439-55. https://doi.org/10.1007/s00441-015-2125-2128

43. Scaglione S, Quarto R, Giannoni P. Stem cells and tissue scaffolds for bone repair. In: DiSilvio L. Cellular response to biomaterials. Boca Raton: CRC Press; 2008.

44. Kargozar S, Hashemian SJ, Soleimani M, Milan PB, Askari $M$, Khalaj $V$, et al. Acceleration of bone regeneration in bioactive glass/gelatin composite scaffolds seeded with bone marrow-derived mesenchymal stem cells over-expressing bonemorphogenetic protein-7. Mater Sci Eng C Mater Biol Appl. 2017;75:688-698. https://doi.org/10.1016/j.msec.2017. 02.097

45. Cancedda R, Giannoni P, Mastrogiacomo M. A tissue engineering approach to bone repair in large animal models and in clinical practice. Biomaterials. 2007;28(29):4240-50. https://doi.org/10.1016/j.biomaterials.2007.06.023

46. Pilipchuk SP, Plonka AB, Monje A, Taut AD, Lanis A, Kang $B$, et al. Tissue engineering for bone regeneration and osseo integration in the oral cavity. Dent Mater. 2015;31(4):317-38. https://doi.org/10.1016/j.dental.2015.01.006

47. Sculean A, Nikolidakis D, Schwarz F. Regeneration of periodontal tissues: combinations of barrier membranes and grafting materials - biological foundation and preclinical evidence: a systematic review. J Clin Periodontol. 2008;35(8Suppl):106-16. https://doi.org/10.1111/j.1600-051X. 2008.01263.x

48. Behring J, Junker R, Walboomers XF, Chessnut B, Jansen JA. Toward guided tissue and bone regeneration: morphology, attachment, proliferation, and migration of cells cultured on collagen barrier membranes: a systematic review. Odontology. 2008;96(1):1-11. https://doi.org/10.1007/s10266-008-0087-y

49. Sakaguchi K, Katagiri W, Osugi M, Kawai T, SugimuraWakayama Y, Hibi $\mathrm{H}$. Periodontal tissue regeneration using the cytokine cocktail mimicking secretomes in the conditioned media from human mesenchymal stem cells. Biochem Biophys Res Commun. 2017;484(1):100-106. https://doi.org/10.1016/j. bbrc.2017.01.065

50. Bottino MC, Thomas V, Schmidt G, Vohra YK, Chu TM, Kowolik MJ, et al. Recent advances in the development of GTR/GBR membranes for periodontal regeneration-a materials perspective. Dent Mater. 2012;28(7):703-21. https://doi.org/10.1016/j.dental.2012.04.022

51. Jazayeri HE, Tahriri M, Razavi M, Khoshroo K, Fahimipour F, Dashtimoghadam $E$, et al. A current overview of materials and strategies for potential use in maxillofacial tissue regeneration. Mater Sci Eng C Mater Biol Appl. 2017;70(Pt 1):913-29. https://doi.org/10.1016/j.msec.2016.08.055

Received on: 17/4/2018 Final version resubmitted on: 5/7/2018 Approved on: 31/7/2018 